B R I L L

\title{
The impact of natural and artificial weathering on the anatomy of selected tropical hardwoods
}

\author{
Miroslava Mamoňová ${ }^{1, *}$ and Ladislav Reinprecht ${ }^{2}$ \\ ${ }^{1}$ Department of Wood Science, Faculty of Wood Sciences and Technology, Technical University in Zvolen, \\ T. G. Masaryka 24, SK-96o or Zvolen, Slovak Republic \\ ${ }^{2}$ Department of Wood Technology, Faculty of Wood Sciences and Technology, Technical University in \\ Zvolen, T. G. Masaryka 24, SK-96o o1 Zvolen, Slovak Republic \\ *Corresponding author; email: mamonova@tuzvo.sk \\ Accepted for publication: 12 May 2020
}

\begin{abstract}
The effect of natural and artificial weathering on the anatomy of seven tropical hardwoods: Bangkirai (Shorea obtusa Wall.), Cumaru (Dipteryx odorata (Aubl.) Wild.), Cumaru Rosa (Dipteryx magnifica (Ducke) Ducke), Ipé (Tabebuia serratifolia Nichols.), Jatobá (Hymenaea courbaril L.), Kusia (Nauclea diderrichii Merill) and Massaranduba (Manilkara bidentata A. Chev.), was studied. As a result of weathering some characteristic anatomical changes occurred: the weakening of connections between cell elements related to the degradation of the middle lamella; micro-cracks in cell walls; total degradation of parenchyma cells in xylem rays, or significant thinning of parenchyma cell walls and their extreme shrinkage; microcracks in the vicinity of xylem rays; significant transversal disruptions in libriform fibres; ablation of pit membranes in vessels and parenchyma cells; changes in the secondary wall of libriform fibres, for example, their defibrillation and weatheringdegradation of the $S_{1}$ layer; and spherical formations on the $S_{3}$ layer of cell walls produced from condensing compounds of degraded lignin and hemicelluloses as well as thermo-mechanical wrinkling. The highest incidence of micro-cracks after both modes of weathering was found in the densest species; Cumaru, Ipé, and Massaranduba.
\end{abstract}

Keywords: Scanning electron microscopy; tropical hardwoods; weathering; degradation; wood anatomical features.

\section{INTRODUCTION}

Currently, the timber of more than forty tropical wood species is imported into Central Europe - mainly from the forests of Papua New Guinea, Indonesia, Brazil, and Cameroon 
(Oliver 2015; ITTO 2017; UNECE 2017). These tropical hardwoods are used mainly for exterior and interior flooring, cladding, doors, windows, interior ceiling panels, and furniture for bathrooms and gardens. However, the focal point of the tropical timber trade is timber processed into profiled deck boards; the so-called decking system, designed for outdoor use.

High-density tropical hardwoods possess specific attributes due to their chemical and anatomical structure; particularly high durability, good dimensional stability, weathering resistance, and resistance to various biological factors (Grace \& Tome 2005; Barreto \& Pastore 2009; Fern et al. 2014; Jankowska et al. 2016; Lacasta et al. 2016).

The high biological resistance of tropical hardwoods is attributed to the presence of various bio-effective extractives, for example, coumarins, flavonoids, and tannins. Furthermore, their strong resistance to outdoor weathering is related to the presence of fats, oils, and waxes, all having hydrophobic properties (Feist \& Hon 1984; Hernández \& Almeida 2003; Grace \& Tome 2005; Waliszewska et al. 2006; Hernández 2007; Hussain et al. 2007). Researchers have studied biological resistance, light stability, colour changes, and chemical changes in tropical hardwood surfaces exposed to weathering, including scientific researchers from the Technical University in Zvolen (Reinprecht et al. 2012; Pánek \& Reinprecht 2016; Mamoňová 2017a; Reinprecht et al. 2018).

There have been some comprehensive studies performed for assessment of weathering phenomena using microscopy and spectroscopy techniques. For example, the chemical kinetics of the weathering process has been studied using NIR spectra (Sandak et al. 2016). In addition, SEM analysis of Norway spruce wood has shown that at the final weathering stage (after 28 days) the exposed surface was very degraded, pits were eroded, cells were delaminated, and advanced pollution and spore deposition on the surface was observed.

The development of cracks and changes in appearance have been investigated mainly in softwoods (Owen et al. 1993; Sandberg \& Söderström 2006) or European beech (Kučera \& Sell 1987). Decomposition of the cell wall takes place in both radial and tangential cell walls, and cracks tend to follow the fibril orientation in the S2-layer of the cell wall (Sandberg \& Söderström 2006). Kučera \& Sell (1987) studied the erosion of the large rays in European beech on tangential surfaces exposed to natural weathering. These authors observed a differential shrinkage of the rays compared to normal wood tissue, partially combined with the photochemical degradation of the wood substance.

In general, weathering causes two types of effects on wood: the destruction of the middle lamella, which supports the premise that the lignin is the photosensitive component in wood and the destruction of pits and changes in cell walls of in xylem tissues (Williams 2005).

Using scanning electron microscopy (SEM) and field emission scanning electron microscopy (FESEM), analyses of the structural integrity of wood species, especially of softwoods related to their natural and artificial UV-weathering were published by Derbyshire et al. (1996); Turkulin \& Sell (1997); Turkulin \& Sell (2002); Evans et al. (2015) and others. Further, many publications and on-line databases address the anatomical description of tropical hardwoods, for example, Ilic (1991); Nardi-Berti \& Edlmann Abbate (1992); Richter \& Dallwitz (2000); InsideWood (2004 onwards) (cf. Wheeler 2011). 
Wood anatomical traits are often studied from the point of view of penetration (Anderegg \& Meinzer 2015) because a substantial proportion of the conductive tissues of tropical woods is blocked by cavitations, tyloses and vessel deposits (De Micco et al. 2016). For an exact description of the seven tropical taxa, we used the terminology of anatomical features in the International Association of Wood Anatomists (IAWA) list of microscopic features for hardwood identification (Wheeler et al. 1989; Wheeler 2011).

The aim of the present anatomical study performed by SEM was to compare the effect of natural and artificial weathering on seven selected tropical hardwoods examining changes in their morphological elements presented on the top surface exposed to weathering. The anatomy of specimens in their natural state was examined in terms of their morphometric characteristics, that is, the tangential vessel diameter and the height of wood rays employing the methods of image analysis integrated into the SEM Tescan Vega. The anatomical study of naturally and artificially weathered tropical woods particularly addresses changes in their mechanical tissues, in the morphology of ray parenchyma, and degradation of intervessel, vessel-ray or vessel-axial parenchyma pit membranes.

\section{MATERIALS AND METHODS}

\section{Tropical woods}

Samples without biological damage, macro-cracks, knots, or other inhomogeneities were prepared from the heartwood of seven tropical wood species occurring in different geographical zones of the world: (1) Bangkirai (Shorea obtusa Wall.), $0.987 \mathrm{~g} / \mathrm{cm}^{3} ;(2)$ Cumaru (Dipteryx odorata (Aubl.) Wild.), $0.996 \mathrm{~g} / \mathrm{cm}^{3}$; (3) Cumaru Rosa (Dipteryx magnifica (Ducke) Ducke), $1.014 \mathrm{~g} / \mathrm{cm}^{3}$; (4) Ipé (Tabebuia serratifolia Nichols.), $1.042 \mathrm{~g} / \mathrm{cm}^{3}$; (5) Jatobá (Hymenaea courbaril L.), $0.907 \mathrm{~g} / \mathrm{cm}^{3}$; (6) Kusia (Nauclea diderrichii Merill), $0.795 \mathrm{~g} / \mathrm{cm}^{3}$; (7) Massaranduba (Manilkara bidentata A. Chev.), $1.012 \mathrm{~g} / \mathrm{cm}^{3}$. For natural weathering, samples $375 \times 78 \times 20 \mathrm{~mm}^{3}$ (longitudinal $\times$ radial $\times$ tangential) were used, and for artificial weathering in a Xenotest, samples $38 \times 38 \times 8 \mathrm{~mm}^{3}$ (longitudinal $\times$ radial $\times$ tangential) were used. Before weathering, the top surfaces of samples were sanded along the grain with 6o-grit sandpaper, followed by 120-grit sandpaper. Transverse ends of samples $\left(78 \times 20 \mathrm{~mm}^{2}\right.$ or $\left.38 \times 8 \mathrm{~mm}^{2}\right)$ were treated with silicone as a protection against water uptake and swelling during weathering.

\section{Natural and artificial weathering}

Natural weathering of the tropical woods was conducted for 36 months in the outside exposition of the Technical University in Zvolen, Slovak republic at an altitude of approximately $300 \mathrm{~m}$ above sea level, and a slope inclination of $45^{\circ}$ south orientation, according to the Standard EN 927-3:2006.

Artificial weathering of the tropical woods was performed for 12 weeks in the Q-SUN Xe-1-S Xenotest (Q-Lab, Westlake, OH, USA), equipped with an 180o-W xenon lamp emitting UV and VIS light, using a Daylight-Q filter, as well as spraying of redistilled water. Each 1-week-long (168 h) exposure cycle was performed according to a partly modified Standard EN 927-6 (2006), as follows: (1) Step $1=24$ h exposition in the dark at $45 \pm 3^{\circ} \mathrm{C}$; (2) step $2=$ 48 sub-cycles each lasting $3 \mathrm{~h}$, first a $2.5 \mathrm{~h}$ exposure to the xenon lamp with UV irradiance 
of $0.55 \mathrm{~W} / \mathrm{m}^{2}$ at $340 \mathrm{~nm}$ using a UVA 340 sensor and then $0.5 \mathrm{~h}$ exposure to water spraying at a temperature of $20 \pm 1^{\circ} \mathrm{C}$.

\section{SEM analyses}

The SEM analyses were conducted on small specimens $\left(1 \mathrm{O}^{-12}\right) \times(1 \mathrm{O}-12) \times\left(5^{-8}\right) \mathrm{mm}^{3}$, which were prepared by sawing from the natural (un-weathered) and weathered tropical hardwood samples, always from the top, central part. The specimens had cut edges at an angle of under $45^{\circ}$, to observe changes in the wood structure created at weathering more clearly, for example, to observe cracks and other disturbances.

To increase the plasticity of the surface layer of wood used for SEM and to achieve an ideal cut, the cutting of specimens was conducted in a fixing bio-holder (a carrot root), which provided moistening and secured an ideal transition of the steel razor blade from the hard xylem as described by Mamoňová (2017b).

Specimens of tropical woods were firstly gold-coated under high vacuum in the device from the company VEB Hochvakuum (Dresden, Germany) and then analysed using the SEM device Tescan Vega (Tescan, Brno, Czech Republic). The accelerating voltage used was between 16.6 and $30.0 \mathrm{kV}$. The electron source was a tungsten filament. The operating conditions (including magnification and scale bar) were recorded on the data-bar at the foot of the SEM image, as in Fig. 1. Determination of changes in the anatomical structure of cells and cell walls of specimens prepared from weathered samples was performed on the top side, with the area of $(10-12) \times(10-12) \mathrm{mm}^{2}$.

Further, specimens of transverse, radial and tangential sections were prepared for a more detailed microscopic analysis of the selected seven tropical wood species from samples not exposed to weathering.

Selected morphometric properties of vessels and wood rays (Tables 1 and 2) were scanned and evaluated using measuring procedures on the cross- or tangential-sections of the tropical hardwood species.

\section{RESULTS AND DISCUSSION}

\section{Anatomy of the natural and weathered tropical woods}

The anatomical structure of the tropical woods was documented in detail before the weathering process (in their natural state) - see summary descriptions and illustrations (Fig. 2, Figs 3-10 column A), to obtain relevant information for a qualitative assessment of the impact of weathering, followed by quantification of the weathering phenomena including the frequency of cracks.

The mean, minimum, and maximum values, standard deviations, and coefficients of variation for the tangential vessel diameters and the ray heights (which have been determined in this work) are presented in Tables 1 and 2, together with values listed in Delta Intkey by Richter \& Dallwitz (2000).

\section{Bangkirai (Shorea obtusa)}

The vessels in Bangkirai wood were diffuse, solitary, and in short radial multiples of 23, or very small clusters (Fig. 2.1). Thin-walled tyloses were present. In the vessels, simple 


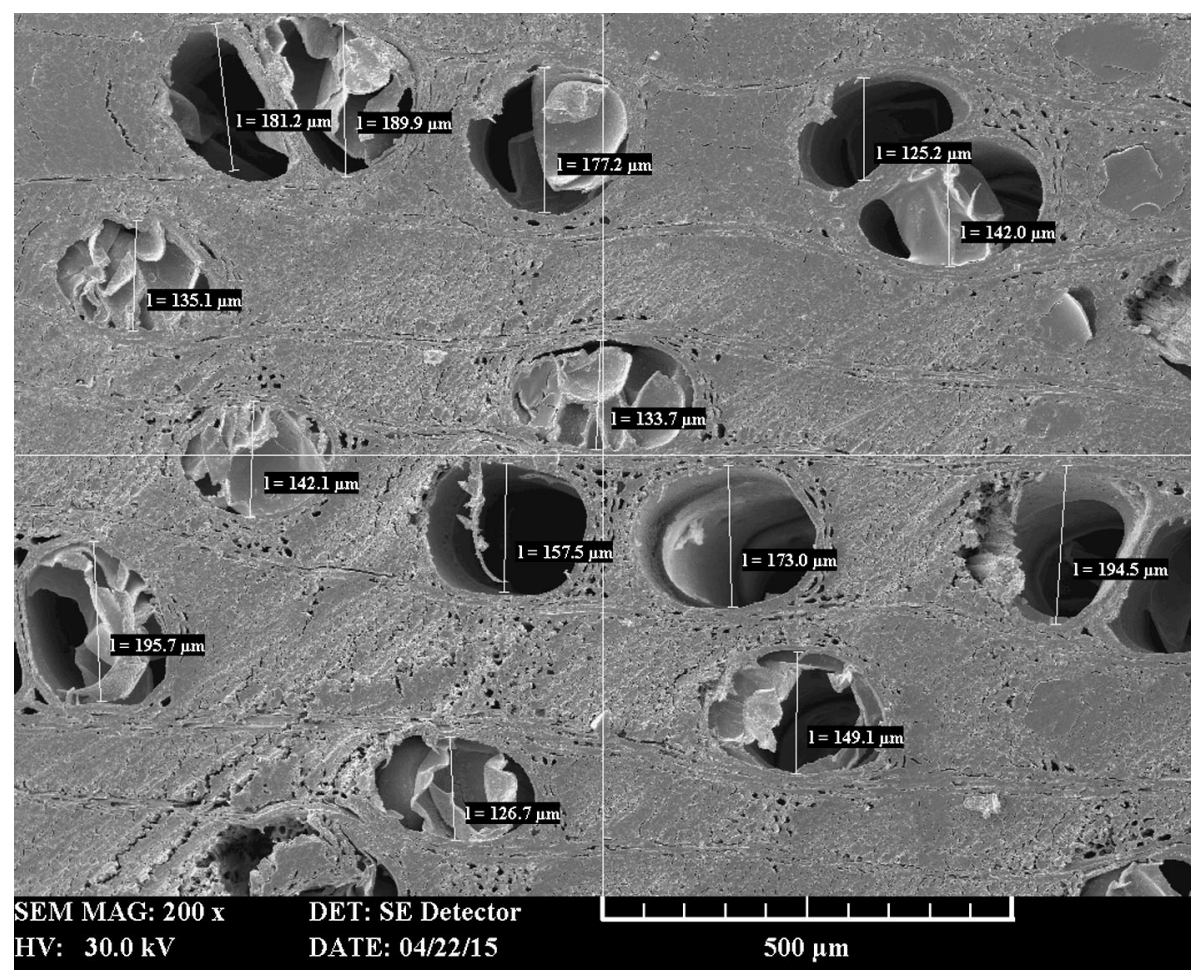

Figure 1. Methodology of scanning of tangential diameters of vessels on a cross-section of Bangkirai wood.

perforations were observed, the inter-vessel pits were scalariform to alternate, and vestured (Fig. 3A3).

The vessels were also surrounded by vascular or vasicentric tracheids. The mechanical tissue was made up of very thick-walled libriform fibres with a small lumen. The crosssections of the Bangkirai wood demonstrated the occurrence of axial resin ducts (Fig. 2.1, arrows) surrounded by apotracheal, tangentially striped, marginal axial parenchyma. Vasicentric parenchyma with subtle aliform and confluent pattern was also observed (Fig. 2.1). Resin ducts, as a characteristic, anatomical feature of the Bangkirai wood, have also been observed by Wheeler et al. (1989). In general, resins may act as a deterrent or have fungicidal properties (Onuorah 2000; Rana et al. 2009).

Rays in the Bangkirai wood are homocellular and heterocellular with square or palisade parenchyma at the margin of each ray having a peripheral row of upright or square cells along a radial section (Fig. $3 \mathrm{Al}$ ). On tangential sections, 3 to 4 -seriate rays prevailed. The height of the rays in this tropical wood reached the highest numbers from among all the species examined, and high variability of measured values up to $35.4 \%$ (Table 2 ) was observed. 

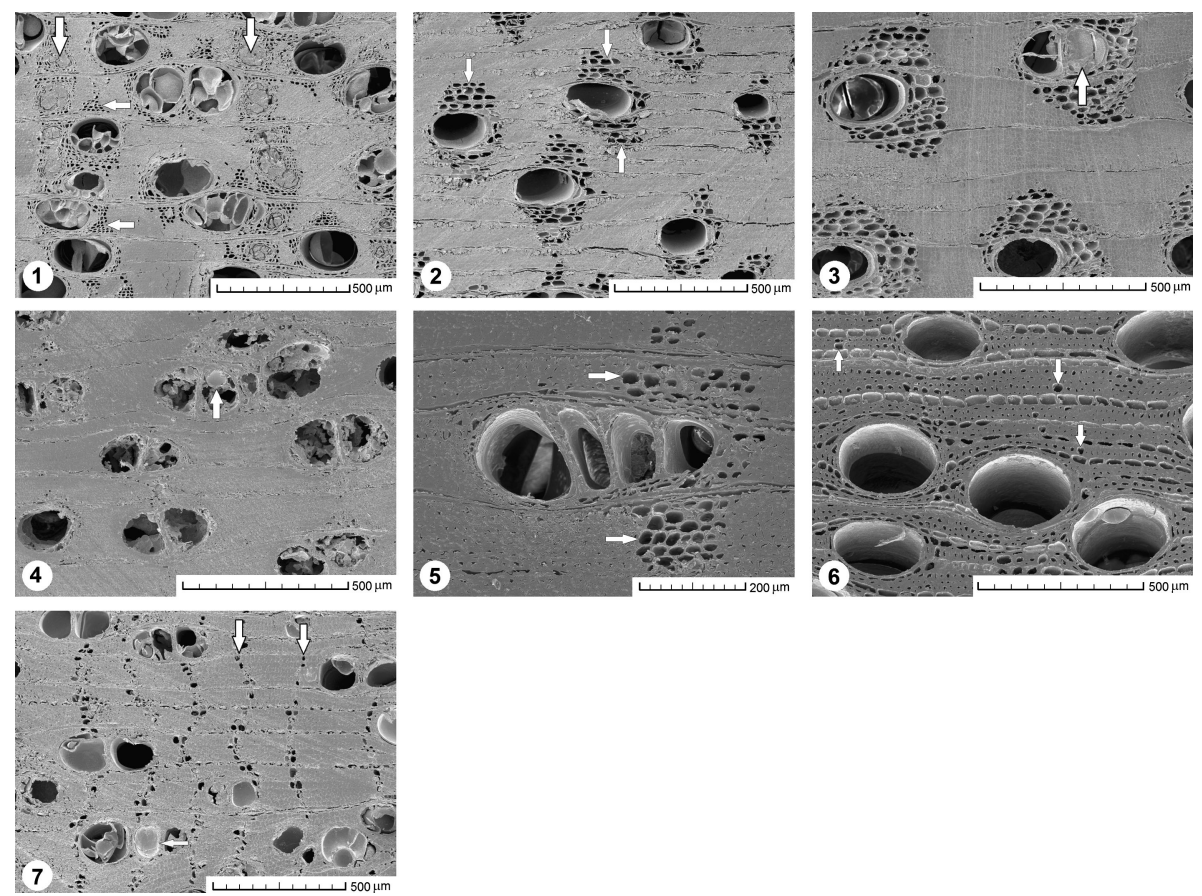

Figure 2. Scanning electron microscopy (SEM) images of the vessel arrangement on the cross-sections of tested tropical woods. (1) Bangkirai, (2) Cumaru, (3) Cumaru Rosa, (4) Ipé, (5) Jatobá, (6) Kusia, (7) Massaranduba. (1) White arrowheads show axial resin ducts in tangential rows. Aliform and confluent axial parenchyma were observed (arrows). (2) Frequent axial parenchyma aliform (arrows). (3) The vessels lacked tyloses, but some lumens of the vessels contained deposits (arrow). (4) Frequent occurrence of small thin-walled tyloses in the vessel lumina (arrow). (5) Unilaterally winged aliform axial parenchyma was observed (arrows). (6) White arrowheads show the exclusive occurrence of apotracheal parenchyma scattered among the fibres. (7) Frequent occurrence of sclerotic tyloses was documented in the vessel lumina (arrow, see also Fig. 10A1). Axial parenchyma is apotracheal, tangentially banded (arrows).

The analysed samples of Shorea obtusa wood had an average density of $0.987 \mathrm{~g} / \mathrm{cm}^{3}$, which is more than Richter \& Dallwitz (2000) specified, but a similar density of 0.94$0.98 \mathrm{~g} / \mathrm{cm}^{3}$ was observed by Schulte et al. (1996) at $12 \%$ moisture content.

- Naturally weathered surfaces of Bangkirai wood were characterised by typical structural changes: the ablation of tyloses from vessels lumina, entirely degraded membranes of inter-vessel pits and ray parenchyma cells (Fig. $3^{\mathrm{B} 1}$ ), the fragile fractures of libriform fibres and cracks in the vicinity of rays encrusted by dust particles and spores (Fig. $3^{\mathrm{B} 2}$ ); Libriform fibres were characteristically defibrillated (Fig. $3^{\mathrm{B}} 3$ ).

- Artificially weathered surfaces were characterised by extreme shrinkage of parenchyma cells and fractures of libriform fibres (Fig. ${ }_{3} \mathrm{C} 1$ ), degraded membranes of vessel pits (Fig. ${ }_{3} \mathrm{C}_{2}$ ) and defibrillation in the secondary wall of libriform fibres (Fig. ${ }_{3} \mathrm{C}_{3}$ ). 

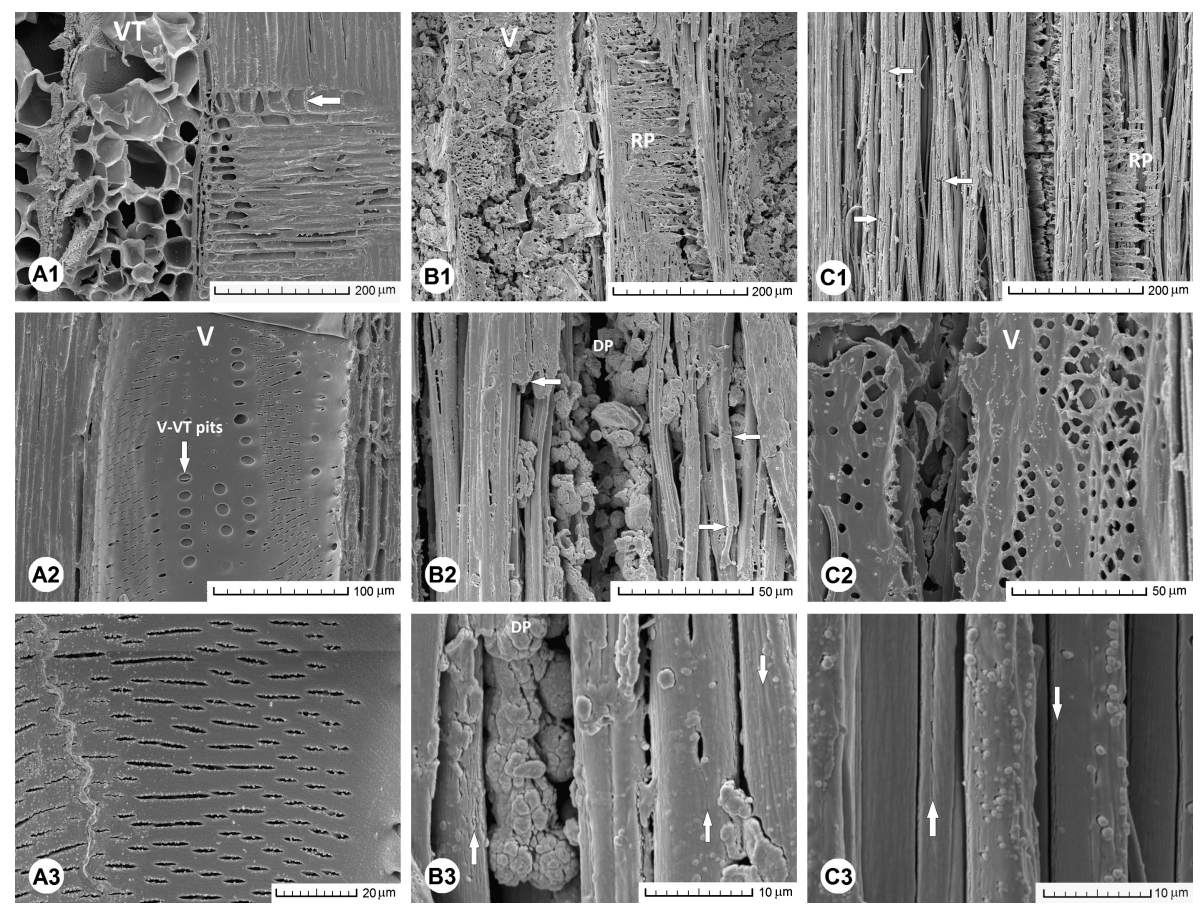

Figure 3. Effect of weathering on the anatomical structure of Bangkirai wood analysed on the tangential surface before and after natural (36 months) or artificial (12 weeks) weathering. (A) Not exposed; (B) 36 months exterior exposure; (C) 12 weeks in the Xenotest. Abbreviations: VT, vessel occluded with tyloses; V, vessel; RP, ray parenchyma cells; V-VT pits, vessel-vasicentric tracheid pits; DP, dust particles and spores and rarely pollen (pollution); RLS, radial-section (in $\mathrm{A}_{1}-\mathrm{A}_{3}$ ).

\section{Cumaru (Dipteryx odorata)}

The vessels in the Cumaru wood were scattered, occurring mostly as solitary (Fig. 2.2) or in short radial groups, usually in groups of two or three and, occasionally, in a group of 5 vessels. The mean value of the tangential diameter of the vessels was $109 \mu \mathrm{m}$, including vessels with a very small diameter (min. value $5^{2} \mu \mathrm{m}$, Table 1), which is slightly less than the values of 100-250 $\mu \mathrm{m}$ specified by Richter \& Dallwitz (2000). Vessel perforations were simple. Inter-vessel pits were alternate, and their shape was oval with vestures (Fig. 4A2). The vessels with vestured pits function as an efficient hydraulic system in plants growing in warm environments with periodic or continuous drought stress (Jansen et al. 2004). The vessels lacked tyloses; however, lumens were filled with deposits.

Cross-sections of the Cumaru wood indicated a significant amount of axial parenchyma, arranged in aliform, lozenge-shaped bundles located around the vessels (Fig. 2.2, arrows). The occurrence of bands of thin-walled axial parenchyma located between thick-walled libriform fibres was also recorded (Fig. $4 \mathrm{~A}_{3}$ ).

Mechanical tissues of libriform fibres in the cross-section are characterised by extremely thickened cell walls and only a tiny lumen, indicating a high density of the Cumaru wood 
Table 1.

Mean vessel diameter of the tested tropical woods and their density.

\begin{tabular}{|c|c|c|c|c|c|c|c|c|}
\hline \multirow[t]{3}{*}{ Trade name } & \multirow[t]{3}{*}{ Species } & \multirow{3}{*}{$\begin{array}{l}\text { Wood } \\
\text { density } \\
\left(\mathrm{g} / \mathrm{cm}^{3}\right)\end{array}$} & \multicolumn{6}{|c|}{ Tangential vessel diameter $(\mu \mathrm{m})$} \\
\hline & & & \multirow[t]{2}{*}{ Mean } & \multirow[t]{2}{*}{ SD } & \multicolumn{2}{|c|}{ Range } & \multirow[t]{2}{*}{$v_{x}(\%)$} & \multirow{2}{*}{$\begin{array}{c}\text { Delta Intkey } \\
\text { (Richter \& } \\
\text { Dallwitz 20oo } \\
\text { onwards) }\end{array}$} \\
\hline & & & & & Min & $\operatorname{Max}$ & & \\
\hline Bangkirai & Shorea obtusa Wall. & 0.987 & $15^{1}$ & 26 & 81 & 204 & 17.4 & $110-170-230$ \\
\hline Cumaru & Dipteryx odorata (Aubl.) Wild. & 0.996 & 109 & 25 & $5^{2}$ & 165 & 22.8 & $100-250$ \\
\hline Cumaru rosa & Dipteryx magnifica (Ducke) Ducke & 1.014 & 144 & 23 & 66 & 189 & $15 \cdot 7$ & missing value \\
\hline Ipé & Tabebuia serratifolia Nichols. & 1.042 & 121 & 20 & 70 & 164 & 16.5 & $6 o-95^{-175}$ \\
\hline Jatobá & Hymenaea courbaril L. & 0.907 & 182 & 46 & 62 & 340 & 25.0 & $75^{-175^{-26 o}}$ \\
\hline Kusia & Nauclea diderrichii Merill & 0.795 & 210 & 35 & 139 & 274 & 16.6 & $140-190-240$ \\
\hline Massaranduba & Manilkara bidentata A. Chev. & 1.012 & 112 & 22 & 45 & 164 & 19.9 & $82-112-150$ \\
\hline
\end{tabular}

$\mathrm{SD}$ is the standard deviation; $v_{x}$ is the coefficient of variation.
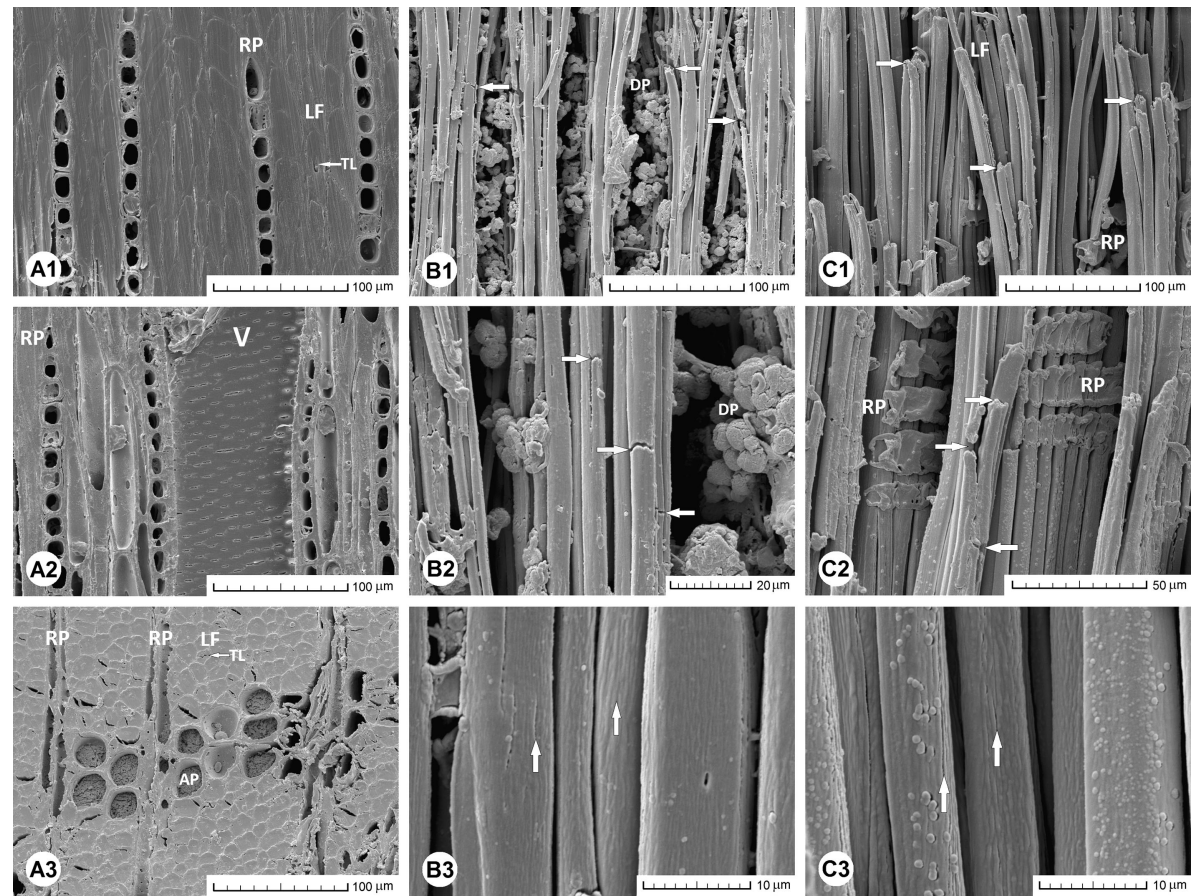

Figure 4. Effect of weathering on the anatomical structure of Cumaru wood analysed on the tangential surface before and after natural (36 months) or artificial (12 weeks) weathering. (A) Not exposed; (B) 36 months in exterior; (C) 12 weeks in the Xenotest. Abbreviations: V, vessel; LF, libriform fibres; TL, tiny lumen; RP, ray parenchyma cells; DP, dust particles and spores and rarely pollen (pollution); AP, axial parenchyma; TLS, tangential section (in A1 and A2); TS, transverse section (in A3). 
Table 2.

Ray height and other characteristics of the tested tropical woods.

\begin{tabular}{|c|c|c|c|c|c|c|c|c|}
\hline \multirow[t]{3}{*}{ Trade name } & \multirow[t]{3}{*}{ Species } & \multicolumn{5}{|c|}{ Ray height $(\mu \mathrm{m})$} & \multicolumn{2}{|c|}{ Rays composition } \\
\hline & & \multirow[t]{2}{*}{ Mean } & \multirow[t]{2}{*}{$\mathrm{SD}$} & \multicolumn{2}{|c|}{ Range } & \multirow[t]{2}{*}{$v_{x}(\%)$} & \multirow[t]{2}{*}{ Width (cells) } & \\
\hline & & & & Min & $\operatorname{Max}$ & & & \\
\hline Bangkirai & $\begin{array}{l}\text { Shorea obtusa } \\
\text { Wall. }\end{array}$ & 605 & 214 & 252 & $105^{8}$ & $35 \cdot 4$ & $(1)-2-4$ & Heterocellular \\
\hline Cumaru & $\begin{array}{l}\text { Dipteryx odorata } \\
\text { (Aubl.) Wild. }\end{array}$ & 247 & $5^{\circ}$ & 113 & 330 & 20.2 & $\begin{array}{l}1-2, \\
\text { predominantly } \\
\text { uniseriate }\end{array}$ & $\begin{array}{l}\text { Homocellular; } \\
\text { storied }\end{array}$ \\
\hline Cumaru rosa & $\begin{array}{l}\text { Dipteryx } \\
\text { magnifica (Ducke) } \\
\text { Ducke }\end{array}$ & 245 & 25 & 177 & 298 & 10.1 & $\begin{array}{l}1-2-(3), \\
\text { predominantly } \\
\text { 2-seriate }\end{array}$ & Homocellular \\
\hline Ipé & $\begin{array}{l}\text { Tabebuia } \\
\text { serratifolia } \\
\text { Nichols. }\end{array}$ & 173 & 27 & 125 & 227 & 15.8 & $\begin{array}{l}2-3-(4), \\
\text { predominantly } \\
\text { 2-seriate }\end{array}$ & homocellular \\
\hline Jatobá & $\begin{array}{l}\text { Hymenaea } \\
\text { courbaril L. }\end{array}$ & $45^{2}$ & 172 & 124 & 962 & $3^{8.1}$ & $\begin{array}{l}1-4-6, \\
\text { predominantly } \\
3 \text {-seriate }\end{array}$ & Homocellular \\
\hline Kusia & $\begin{array}{l}\text { Nauclea } \\
\text { diderrichii Merill }\end{array}$ & 545 & 170 & 219 & 965 & 31.1 & $1-2-3$ & $\begin{array}{l}\text { Heterocellular; } \\
\text { uniseriates } \\
\text { often } \\
\text { homocellular }\end{array}$ \\
\hline Massaranduba & $\begin{array}{l}\text { Manilkara } \\
\text { bidentata A. Chev. }\end{array}$ & 337 & 100 & 172 & 554 & 29.8 & $\begin{array}{l}\text { (1)-2 (rarely } \\
3 \text {-seriate). }\end{array}$ & Heterocellular \\
\hline
\end{tabular}

$\mathrm{SD}$ is the standard deviation; $v_{x}$ is the coefficient of variation.

(Fig. 2.2; Fig. 4A3). The average density of Dipteryx odorata was $0.996 \mathrm{~g} / \mathrm{cm}^{3}$. Microscopic sections exhibited strongly interlocked grain, which had previously been determined and discussed by Hernández \& Almeida (2003).

The rays of the Cumaru wood were uniseriate. All rays were storied (Fig. 4A1), and homocellular as seen in the tangential and radial sections, consisting of radial parenchyma cells, (ray cells were procumbent). The height of the rays ranged from $113-330 \mu \mathrm{m}$, with a mean value of $247 \mu \mathrm{m}$ (Table 2).

- Naturally weathered surfaces of Cumaru wood were characterised by fragile fractures of libriform fibres and cracks in the uniseriate rays encrusted by dust particles, spores, and rarely pollen (Fig. $4 \mathrm{~B} 2$ ). The defibrillation in the secondary wall of libriform fibres was observed on the weathered surface (Fig. 4B3).

- Artificially weathered surfaces were characterised by the multiple fractures of libriform fibres (Fig $4 \mathrm{C} 1$ ), an extreme shrinkage of ray parenchyma cells (Fig. ${ }_{4} \mathrm{C} 2$ ) and spherical 

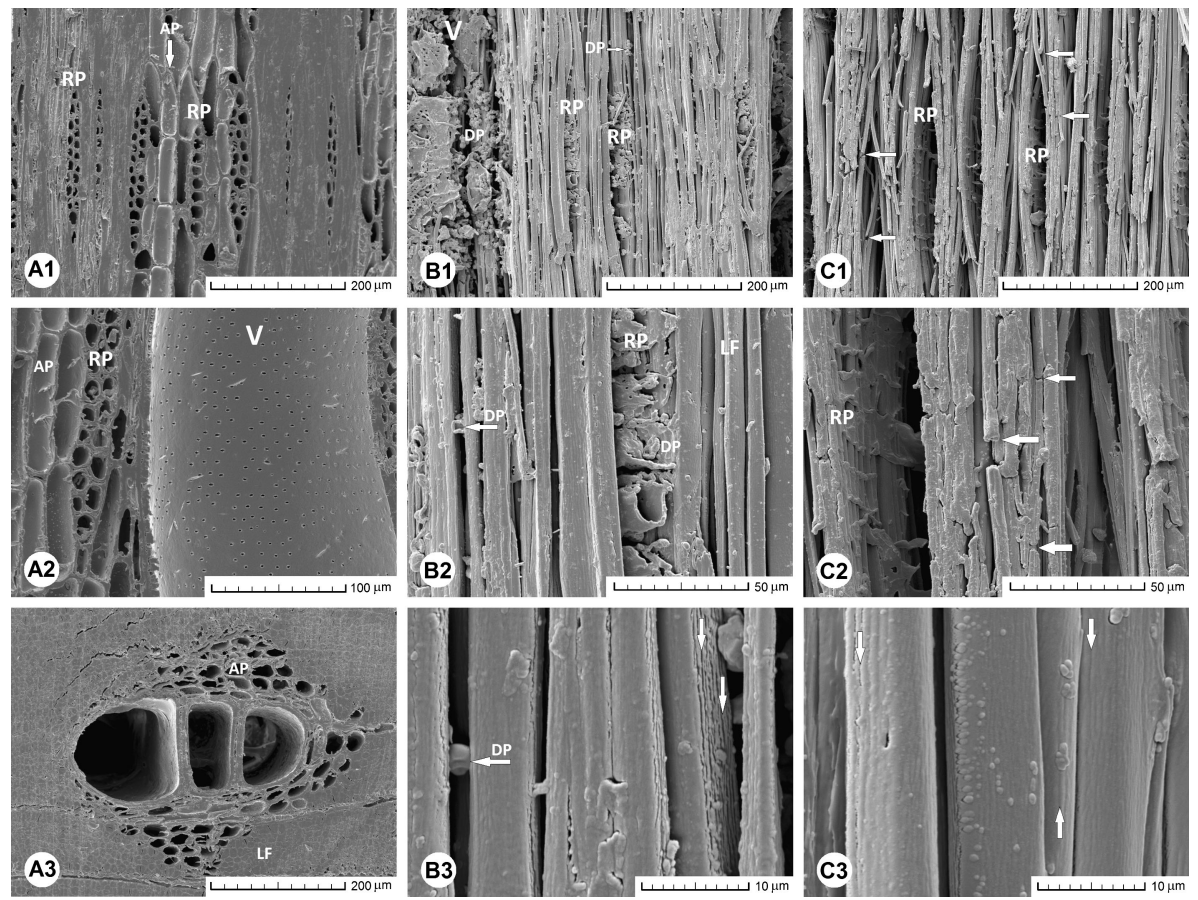

Figure 5. Effect of weathering on the anatomical structure of Cumaru Rosa wood analysed on the tangential surface before and after natural (36 months) or artificial (12 weeks) weathering. (A) Not exposed; (B) 36 months in exterior; (C) 12 weeks in the Xenotest. Abbreviations: V, vessel; LF, libriform fibres; TL = tiny lumen; RP, ray parenchyma cells; DP, dust particles and spores and rarely pollen (pollution); AP, axial parenchyma; TLS, tangential section (in A1 and A2); TS, transverse section (in A3).

formations on the secondary walls of libriform fibres produced from condensing compounds of degraded lignin and hemicelluloses as well as thermo-mechanical wrinkling (Fig. $4 \mathrm{C}_{3}$ ).

\section{Cumaru Rosa (Dipteryx magnifica)}

Cross-sections of Cumaru Rosa wood (Fig. 2.3) showed that the vessels were mostly solitary, with lozenge-aliform parenchyma, sporadically turning into confluent parenchyma. Occasionally, radial groups of 3 vessels were observed (Fig. $5 \mathrm{~A}_{3}$ ). The mean value of the tangential vessel diameter was $144 \mu \mathrm{m}$; compared with Cumaru, the range of tangential vessel diameter shifted to higher values $(66-189 \mu \mathrm{m}$, Table 1). The coefficient of variation for vessel diameters of $15.7 \%$ was the lowest of all the tropical wood species examined.

Inter-vessel pits of $D$. magnifica were minute and densely arranged, in comparison with $D$. odorata, with an inter-vessel pit size of $<4 \mu \mathrm{m}$, in an opposite arrangement. The shape of inter-vessel pits was circular and vestured (compare Fig. 4A2 and Fig. $5 \mathrm{~A} 2$ ). The size of intervascular pits has been reported to provide a good distinguishing feature in the family Dipterygeae (Gasson 1999; Lewis \& Gasson 2000). The vessels lacked tyloses. 
The mechanical tissues contained libriform fibres with extremely thickened cell walls and a tiny lumen in the cross-section of the Cumaru Rosa wood indicating high density (Fig. 5A3); the average density of the samples was $1.014 \mathrm{~g} / \mathrm{cm}^{3}$.

In the tangential sections of the Cumaru Rosa wood, biseriate rays dominated (Fig. ${ }_{5}^{\mathrm{Ar}}$ ), all rays were storied and homocellular, consisting of procumbent cells. The mean value of the ray height did not significantly differ from the ray height in $D$. odorata. However, the lower coefficient of variation of $10.1 \%$ is noteworthy (Table 2).

- Naturally weathered surfaces of Cumaru Rosa wood were characterized by less shrinkage of ray parenchyma cells than during artificial weathering (Fig. $5^{\mathrm{B} 2}$ ), the loosened middle lamella between libriform fibres encrusted by dust particles (Fig. $5^{\mathrm{B} 2}$, B3) and defibrillation in the secondary wall of libriform fibres on the weathered surface (Fig. 5B3). $^{\mathrm{B}}$.

- Artificially weathered surfaces were characterised by multiple fractures of libriform fibres (Fig. ${ }_{5} \mathrm{Cl}$ ), an extreme shrinkage of ray parenchyma cells, or their ablation (Fig. ${ }^{\mathrm{C} 2} 2$ ).

\section{Ipé (Tabebuia serratifolia)}

The vessels in Ipé wood were scattered, partly solitary, or arranged in radial pairs. They were medium-sized and of circular cross-section (Fig. 2.4). Tiny thin-walled tyloses were frequently observed in the vessel lumina (Fig. 6A1). The vessels and parenchyma cells also contained deposits (Fig. 6A1, $\mathrm{A}_{3}$ ) indicative of the presence of organic compounds known as "lapachol" or "ipeina" (Dos Santos \& Miller 1992; Pace et al. 2015). Lapachol (naphthoquinone) was first described in Tabebuia avellanedae in the 19th century. It exhibits antimicrobial properties and has numerous applications in pharmacology (Hussain et al. 2007).

The mean value of the tangential vessel diameter in Ipé wood was $121 \mu \mathrm{m}$ (Table 1). This is a higher value than the value of $95 \mu \mathrm{m}$ proposed by Richter \& Dallwitz (2000); however, it coincides with the interval values they presented.

Vessel elements exclusively showed simple perforation plates. However, the rare occurrence of other types of multiple perforation plates as listed in InsideWood (Wheeler 2011; Pace et al. 2015) cannot be ruled out. Inter-vessel pits were often alternate, although scalariform inter-vessel pits were also present (Fig. 6A3), which have not been previously documented.

Axial parenchyma did not form any characteristic pattern on transverse sections. It occurred in the form of short discontinuous parenchyma bands 1-2 cells wide. The vessels were surrounded in vasicentric, aliform, or even unilaterally confluent, axial parenchyma. The mechanical tissue of Ipé wood was composed of fairly thick-walled libriform fibres, which was reflected in its high mean density $\left(1.042 \mathrm{~g} / \mathrm{cm}^{3}\right)$.

The wood rays of Ipé wood were homocellular, narrow, with the prevalence of biseriate, or sporadically 3 -seriate rays, (Fig. 6A2), while uniseriate rays were absent and all rays were storied. Ipé wood, according to the heights of wood rays in tangential sections, ranks among the wood species with small wood rays, similar to the genus Dipteryx (Cumaru or Cumaru Rosa). The height of rays ranged within the interval of $125^{-227} \mu \mathrm{m}$, with low variability of 

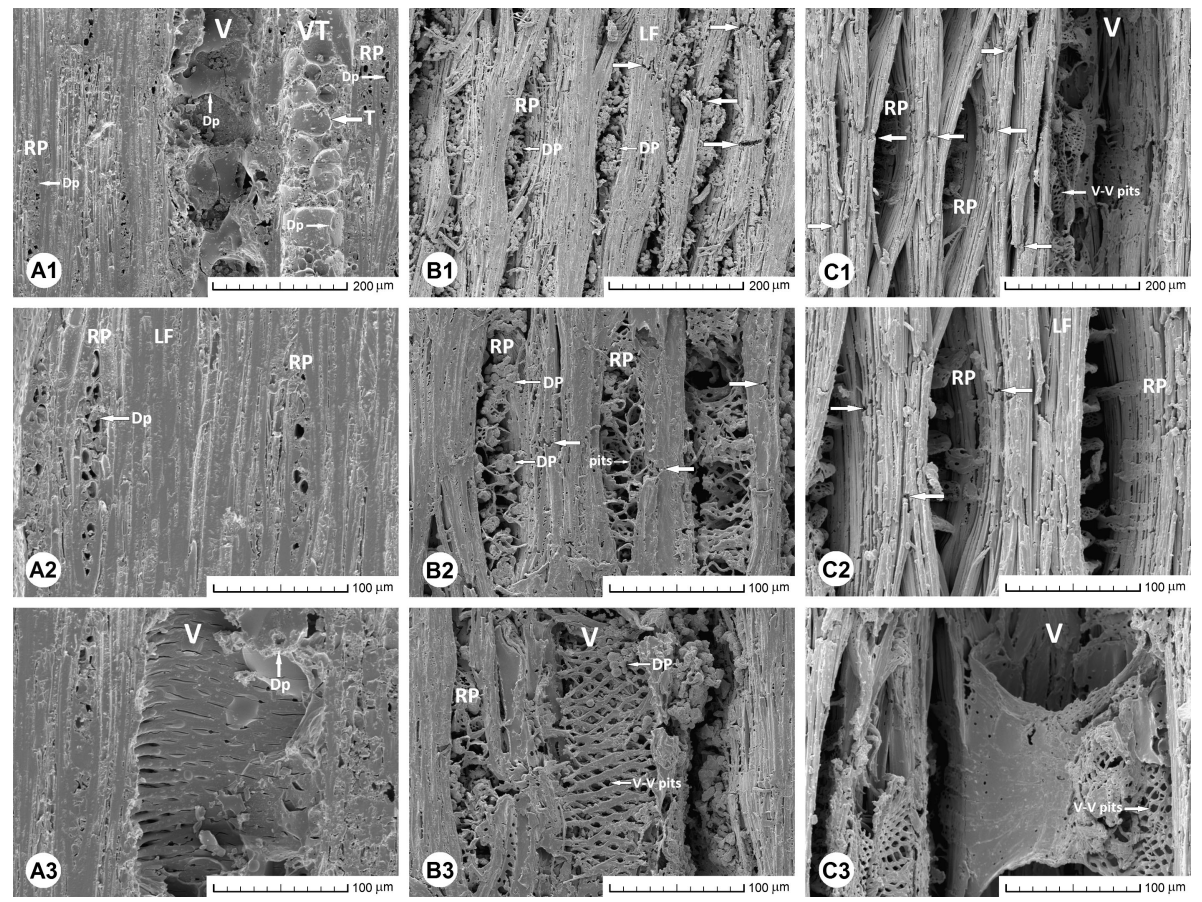

Figure 6. Effect of weathering on the anatomical structure of Ipé wood analysed on the tangential surface before and after natural ( 36 months) or artificial (12 weeks) weathering. (A) Not exposed; (B) 36 months in exterior; (C) 12 weeks in the Xenotest. Abbreviations: V, vessel; VT, vessel occluded with tyloses; T, tylosis; V-V pits, inter-vessels pits; LF, libriform fibres; RP, ray parenchyma cells; DP, dust particles and spores and rarely pollen (pollution); Dp, deposits, organic compounds (naphthoquinone); TLS, tangential section (in $\mathrm{A}_{1}-\mathrm{A} 3$ ).

measured values (15.8\%, Table 2). According to Richter \& Dallwitz (2000), the height of rays in the wood species Tabebuia Spp. can reach up to $500 \mu \mathrm{m}$.

- Naturally weathered surfaces of Ipé wood were characterised by fragile fractures of the libriform fibres, cracks in the vicinity of rays encrusted by dust particles (Fig. 6B2), and evident ablation of inter-vessel pit membranes at the weathered surface (Fig. 6B3).

- Artificially weathered surfaces were characterised by an extreme shrinkage or degradation of ray parenchyma cells and fractures of libriform fibres (Fig. 6C1, C2), the large dilatation of the ray space, crack formation (Fig. $6 \mathrm{C}_{2}$ ) and evident ablation of intervessel pits membranes (Fig. 6C 3 ).

\section{Jatobá (Hymenaea courbaril)}

The vessels of Jatobá wood were scattered, partly solitary, partly in radial multiples of $2-3$, and occasionally forming clusters. The vessels were sporadically arranged in radial clusters of four (Fig. 2.5), but more often in radial pairs (Fig. 7 $\mathrm{A}_{3}$ ). 

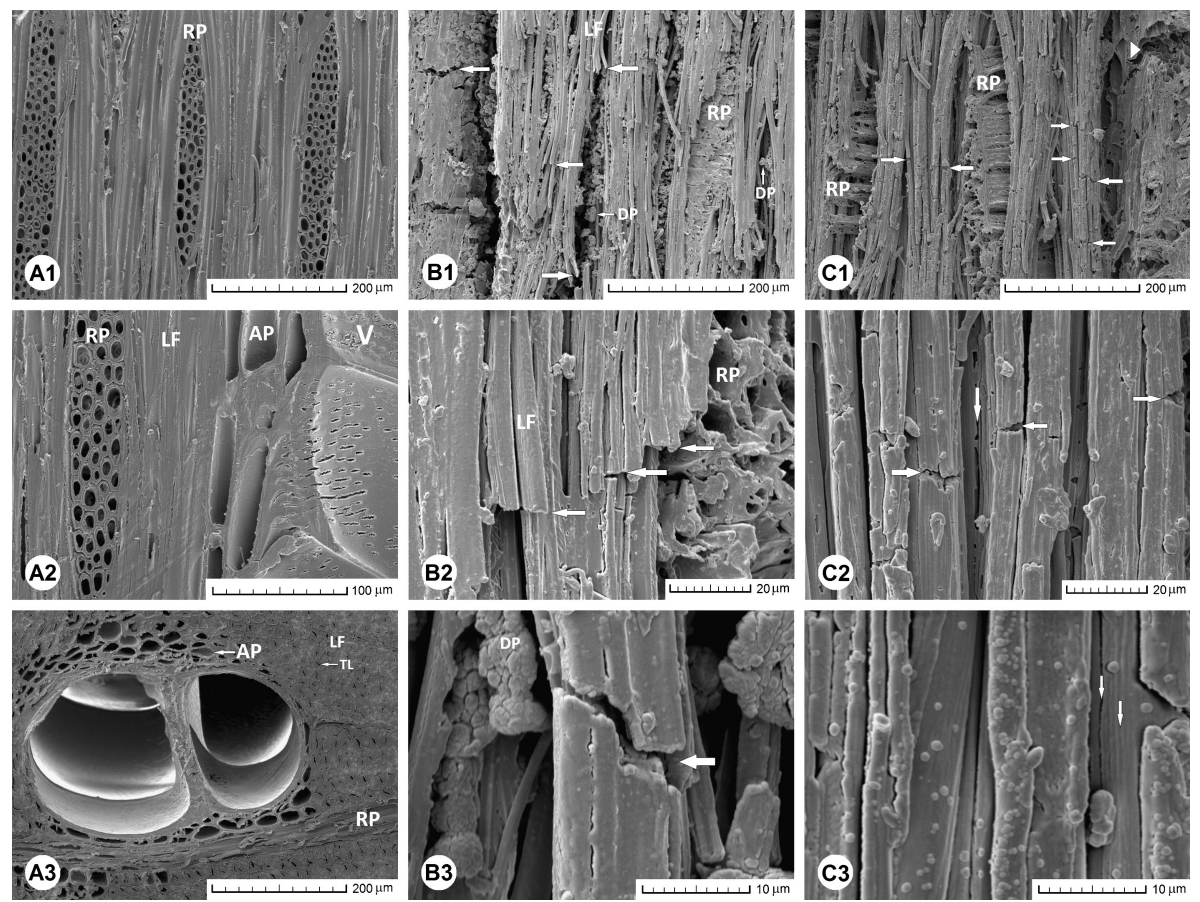

Figure 7. Effect of weathering on the anatomical structure of Jatobá wood analysed on the tangential surface before and after natural ( 36 months) or artificial (12 weeks) weathering. (A) Not exposed; (B) 36 months in exterior; (C) 12 weeks in the Xenotest. Abbreviations: $\mathrm{V}$, vessel; LF, libriform fibres; $\mathrm{TL}=$ tiny lumen; RP, ray parenchyma cells; AP, axial parenchyma; DP, dust particles and spores and rarely pollen (pollution); TLS, tangential section (in A1 and A2); TS, transverse section (in A3).

Examination of cross-sections of Jatobá wood demonstrated a low number of large vessels. The mean value of tangential vessel diameter reached $182 \mu \mathrm{m}$ (Table 1), in agreement with the study conducted by Richter \& Dallwitz (200o) which reported a mean of $175 \mu \mathrm{m}$. However, this study found a wider range shifting towards higher values, as well as the occurrence of vessels of larger diameter (max. value $340 \mu \mathrm{m}$, Table 1 ). The coefficient of variation for vessel diameters of Jatobá wood was $25.0 \%$, which represents the highest value of the seven wood species. The vessel diameter values closely correspond with those presented by Wagenführ (2007), and with the data proposed by Melandri \& Espinoza de Pernía (2009), who found the vessel diameters in Jatobá wood to be 90-300 $\mu \mathrm{m}$.

The vessels had simple perforations. Inter-vessel pits were scalariform to alternate. Intervessel pits were vestured (Fig. $7 \mathrm{~A} 2$ ). Vessels did not present tyloses. However, the sporadic occurrence of deposits in the lumens of heartwood vessels was observed.

Predominantly lozenged, or unilaterally winged aliform, paratracheal, axialparenchyma was observed surrounding the vessels in cross-sections (Fig. 2.5). Marginal axial parenchyma bands were present. Growth ring boundaries were demarcated by marginal parenchyma. 
The mechanical tissue of Jatobá wood was formed by numerous thick-walled fibres (Fig. $7 \mathrm{~A}_{3}$ ). This was also reflected in the high average density of the analysed samples $\left(0.907 \mathrm{~g} / \mathrm{cm}^{3}\right)$, which exceeded the higher value in the range $0.71-0.9 \mathrm{~g} / \mathrm{cm}^{3}$ proposed by Richter \& Dalwitz (2000). The occurrence of thin-walled, libriform fibres with a wide lumen reported by Wagenführ (2007) was not observed in our specimens. Alves and AngyalossyAlfonso (2002) claim that the fibre cell-wall thickness is related to humidity and growth of the Jatobá tree, that is, thicker walls are associated with drier environments and lower latitudes.

The rays of the Jatobá wood were homocellular, multiseriate (Fig. 7A1), 4-6 cells wide, but most commonly 5 cells wide (Fig. $7 \mathrm{~A} 2$ ) with a rare occurrence of short uniseriate rays. Storied structure was absent. Jatobá wood, according to the heights of wood rays in tangential section specimens, ranks among the wood species with high wood rays, similar to genus Shorea (Bangkirai) and genus Nauclea (Kusia). The height of rays ranged within the interval of $124-962 \mu \mathrm{m}$, with the highest variability of measured values (38.1\%, Table 2 ). Our measurements also revealed very tall rays that have not been mentioned in the literature to date. Wagenführ (2007) presented the occurrence of a maximum ray width of 5 cells in $\mathrm{Hy}$ menaea coubaril with a maximum height of $720 \mu \mathrm{m}$ and a mean value of $420 \mu \mathrm{m}$. Melandri \& Espinoza de Pernía (2009) indicated rays with a maximum height value of $650 \mu \mathrm{m}$, while $65 \%$ reached a height within the range $192-450 \mu \mathrm{m}$.

- Naturally weathered surfaces of Jatobá wood were characterised by transversal fragile fractures of libriform fibres (Fig. 7 B2, B3).

- Artificially weathered surfaces were characterised by an extreme shrinkage of parenchyma cells (Fig. ${ }_{7} \mathrm{Cl}$ ), fractures of libriform fibres (Fig. ${ }_{7} \mathrm{C} 2$ ) and the occurrence of spherical structures on the surface of fibre walls as well as pronounced thermomechanical wrinkling (Fig. ${ }_{7} \mathrm{C}_{3}$ ).

\section{Kusia (Nauclea diderrichii)}

Arrangement of the vessels in Kusia wood was scattered. The occurrence of large, oval, and exclusively solitary vessels was recorded on cross-sections (Fig. 2.6). The mean value of the tangential vessel diameter of Kusia was the largest of all examined tropical wood species $(210 \mu \mathrm{m}$, Table 1$)$, with a low coefficient of variation (16.6\%) supporting consistency size. Compared with the vessel diameter values presented by other authors (Richter \& Dallwitz 2000; Wagenführ 2007), an upward shift of the value range was observed. This was because small vessels, as described by Wagenführ (2007) — with the minimum vessel diameter of $78 \mu \mathrm{m}$ - were not found in the cross-sections of our Kusia wood specimens.

The vessels had simple perforations and their inter-vessel pits were scalariform to alternate. Inter-vessel pits were vestured (Fig. 8A1). Tyloses in vessels were absent, however, the sporadic occurrence of deposits in the lumens of heartwood vessels was observed. The vessel element walls exhibited the incidence of fine helical thickenings (Fig. 8A1), which has not previously been described in the literature.

Cross-sections of Kusia wood exhibited only apotracheal parenchyma (Fig. 2.6, arrows) scattered among the fibres, or arranged in short tangential bands. 

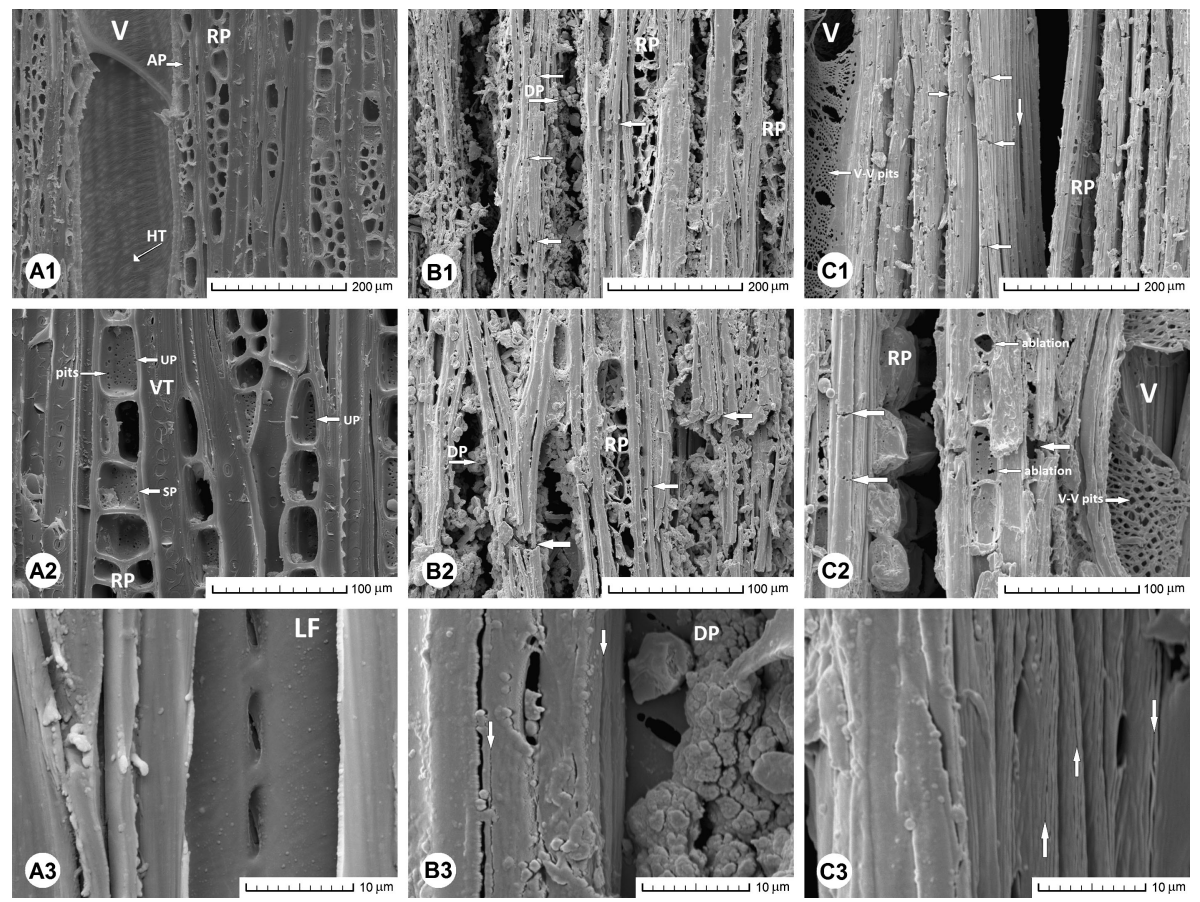

Figure 8. Effect of weathering on the anatomical structure of Kusia wood analysed on the tangential surface before and after natural ( 36 months) or artificial (12 weeks) weathering. (A) Not exposed; (B) 36 months in exterior; (C) 12 weeks in the Xenotest. Abbreviations: V, vessel; LF, moderately thickwalled libriform fibres; RP, ray parenchyma cells; DP, dust particles and spores and rarely pollen (pollution); UP, upright parenchyma cell; SP, square parenchyma cell; VT, vascular tracheid; AP, axial parenchyma; HT, helical thickenings; TLS, tangential section (in $\mathrm{A}_{1}-\mathrm{A}_{3}$ ).

The wood rays were homocellular, often uniseriate (composed of square or palisade parenchyma) as well as heterocellular, and bi- or 3 -seriate (with peripheral rows of upright or square parenchyma cells) (Fig. 8A2; Fig. 9.2).

Kusia wood according to the heights of the wood rays of tangential section specimens ranks among the wood species with tall wood rays with a high variability of measured values (31.1\%, Table 2). The ray height ranged between 219 and $965 \mu \mathrm{m}$, and the mean value was $545 \mu \mathrm{m}$. Notably higher rays were indicated by Wagenführ (2007), with the maximum ray height in Nauclea diderrichii of $2100 \mu \mathrm{m}$ and a relatively higher mean value of $725 \mu \mathrm{m}$. The ray cells also contained microcrystals in the form of crystal sand (Fig. 9.1) as also mentioned by Ogata et al. (2008).

The mechanical tissue of Kusia wood is formed by moderately thick-walled libriform fibres (Fig. 2.6), which resulted in a relatively low mean density of the experimental samples $\left(0.795 \mathrm{~g} / \mathrm{cm}^{3}\right)$ which was the lowest value of all examined tropical wood species. Intervessel pits were observed on both radial and tangential walls and were distinctly delineated. Both septate and non-septate fibres were present. The occurrence of vascular or vasicentric 

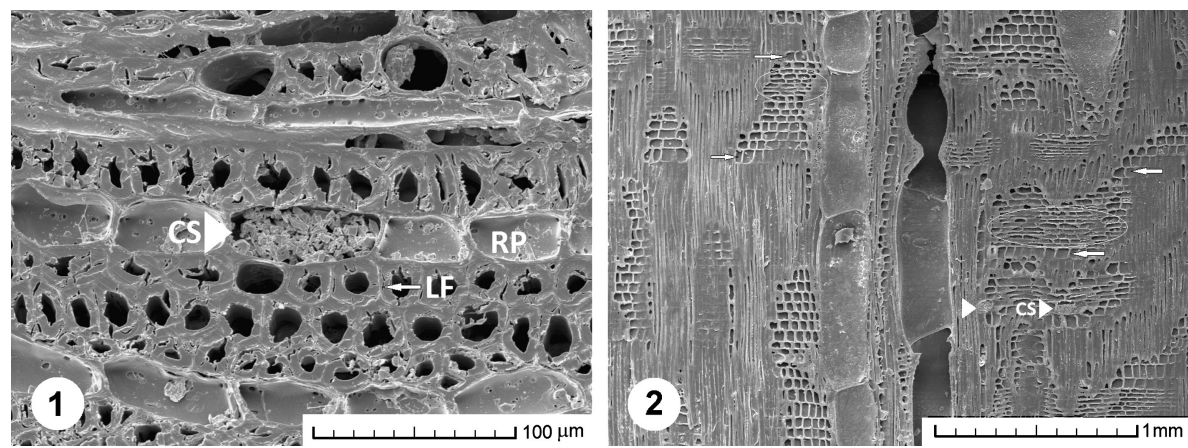

Figure 9. Anatomical features of Kusia wood showing unusual features. (1) Ray cells contained microcrystals in a form of crystal sand, TS. (2) Heterocellular rays, body ray cells procumbent (highlighted by an ellipse) with peripheral rows of upright or square parenchyma cells (arrows); crystal sand located in ray cells, RLS. Abbreviations: RP, ray parenchyma cells; CS, crystal sand; LF, libriform fibre; TS, transverse section; RLS, radial section.

tracheids was documented around the vessels. Their presence was also reported by other authors (Wheeler et al. 1989; Richter \& Dallwitz 2000).

- Naturally weathered surfaces of Kusia wood were characterised by degradation of parenchyma cells in xylem rays and the mild dilatation of the ray space (Fig. 8B1), fractures of libriform fibres, cracks in the vicinity of rays encrusted by dust particles (Fig $8 \mathrm{~B} 2)$ and defibrillation in the secondary wall of libriform fibres at the weathered surface (Fig $\left.8 \mathrm{~B}_{3}\right)$.

- Artificially weathered surfaces were characterised by fragile fractures of libriform fibres (Fig 8C1, C2), the dilatation of the ray space and the ablation of pits membranes (Fig $8 \mathrm{C} 2$ ) as well as pronounced thermo-mechanical wrinkling (Fig 8C3).

\section{Massaranduba (Manilkara bidentata)}

The vessels in Massaranduba wood were scattered, typically arranged in short radial rows, and mainly in pairs (Fig. 2.7). The frequent occurrence of sclerotic tyloses was documented in the vessel lumens (Fig. 10A1). Massaranduba and Cumaru wood species both exhibited the lowest means of tangential vessel diameter of all studied tropical wood species. The mean of tangential vessel diameter in Massaranduba wood reached the value of $112 \mu \mathrm{m}$, although vessels of smaller diameters were also recorded (min. value $45 \mu \mathrm{m}$, Table 1). Thus, we were able to refine the interval for Massaranduba wood vessels measured by Richter \& Dallwitz (2000). Inter-vessel pits were scalariform to opposite (Fig. 10A2).

Axial parenchyma was apotracheal, tangentially banded, and diffuse in aggregates (Fig. 2.7, arrows). Libriform fibres were very thick-walled, which can be observed in the close-up of a tangential section (Fig. 10A3). No occurrence of vascular or vasicentric tracheids was documented, as opposed to the studies conducted by Wheeler et al. (1989) or Richter \& Dallwitz (2000). 

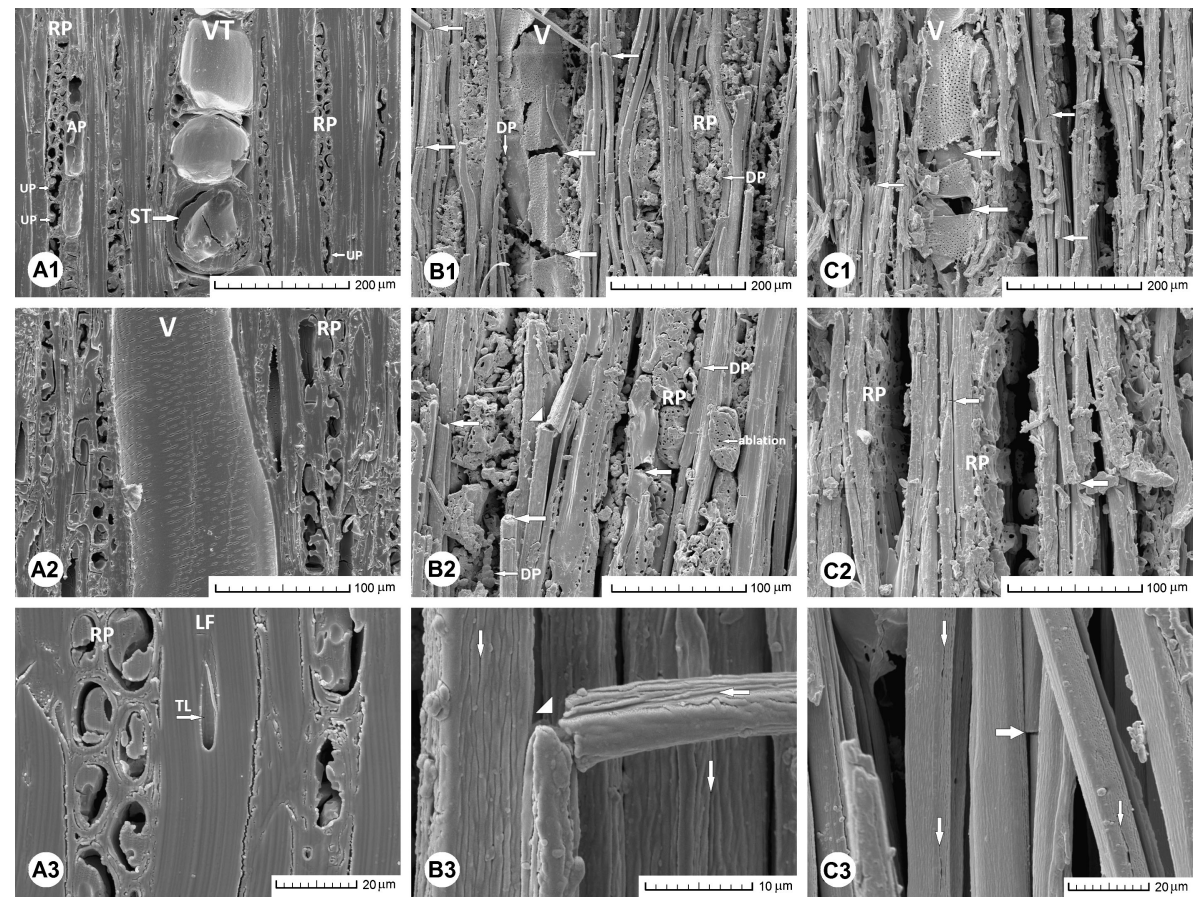

Figure 10. Effect of weathering on the anatomical structure of Massaranduba wood analysed on the tangential surface before and after natural (36 months) or artificial (12 weeks) weathering. (A) Not exposed; (B) 36 months in exterior; (C) 12 weeks in the Xenotest. Abbreviations: VT, vessel occluded with tyloses; V, vessel; ST, sclerotic tyloses; RP, ray parenchyma cells; UP, upright parenchyma cell; AP, axial parenchyma; DP, dust particles and spores and rarely pollen (pollution); LF, libriform fibres; TL, tiny lumen; TLS, tangential-section (in $\mathrm{A}_{1}-\mathrm{A}_{3}$ ).

The xylem rays were heterocellular often composed of two or more cell types with square and palisade parenchyma concentrated along the ray edge (1-3 rows of upright or square marginal cells, Fig. 10A1). The rays were predominantly biseriate with some uniseriate. No 3 -seriate rays were observed on tangential sections. All ray parenchyma cells exhibited inclusions of heartwood substances (Fig. 10A3). The ray height ranged between 172 and $554 \mu \mathrm{m}$, with the mean value of $337 \mu \mathrm{m}$ (Table 2).

- Naturally weathered surfaces of Massaranduba wood were characterised by the fragile fractures of libriform fibres and evident ablation of pits membranes at the weathered surface (Fig. 1oB2). The secondary wall of libriform fibres showed defibrillation at the weathered surface (Fig. 10B3).

- Artificially weathered surfaces were characterised by an extreme shrinkage of parenchyma cells and fractures of libriform fibres (Fig. 10C1), fragile fractures transversal disruptions of libriform fibres and micro-cracks in the vicinity of xylem rays (Fig. ${ }_{10 C}$ ), as well as pronounced thermo-mechanical wrinkling (Fig. ${ }_{10 C}$ ). 


\section{Effect of weathering on the anatomical structure of tropical woods}

Natural weathering without ground contact (Figs 3-10, column B) resulted in the loosening of the individual cell elements at the top surfaces of all seven tropical woods. The formation of radial cracks was also observed. The parenchyma cells of the wood rays were completely degraded, and in cases where the parenchyma tissue was preserved, its cell walls became particularly thin. The empty spaces after the wood rays were encrusted by dust, spores, and rarely, pollen. Brittle, perpendicular fractures formed on libriform fibres, that indicated degradation of the secondary cell walls. All wood species exhibited fibrillation of the secondary wall of libriform fibres. The membranes of inter-vessel pits and parenchyma cells were entirely degraded.

During artificial weathering in the Xenotest (Figs 3-10, column C), radial cracks also occurred, similar to those for natural weathering, however, encrustation of cells by various particles from the air was not observed. As in the case of natural weathering, degradation of all exposed areas took place. Parenchyma cells underwent significant shrinkage which could be readily recognised on the Cumaru wood (Fig. $4 \mathrm{C} 2$ ). The surface structure of all tropical species exhibited an abundance of brittle transverse fractures in libriform fibres (Fig. $7 \mathrm{C} 2$ ). Spherical structures were observed on the surface of the lumens (for example the appearance of small spherical-like droplets could be seen) probably resulting from condensing compounds of lignin and degradation products of hemicelluloses on the surface of cell walls, as well as pronounced thermo-mechanical wrinkling (Fig. ${ }_{3} \mathrm{C}_{3}$; Fig. ${ }_{7} \mathrm{C}_{3}$ ).

Micro-cracks in the naturally and artificially weathered surfaces of tropical woods (Table 3) depended on additional factors, such as wood density, the morphology of xylem rays, and weathering conditions.

It has been demonstrated that wood density has a significant impact on crack formation in the area of the rays. The highest micro-cracks for both modes of weathering were usually determined on surfaces of more dense wood species. In line with this, the largest relative changes of dilatation of the ray space due to weathering were found in Cumaru, Ipé, and Massaranduba (Table $3, K_{\mathrm{N}}$ and $K_{\mathrm{A}}$ from 95 to $191 \%$ ). The highest absolute dilatation values of ray spaces (created micro-cracks) after natural weathering were on the top surfaces of Massaranduba wood (Table 3, micro-cracks $5^{2} \pm 11.6 \mu \mathrm{m}$ ). However, the largest micro-cracks in absolute values after artificial weathering occurred in Jatobá (Table 3, micro-cracks $73 \pm$ $24.5 \mu \mathrm{m}$ ) having the widest rays $39 \pm 16.2 \mu \mathrm{m}$. Generally, the absolute values of micro-cracks depended not only on wood density (Fig. 11), but also on the original morphology of individual wood species (Table 3 ).

Comparing the creation of micro-cracks for two very similar tropical woods (Cumaru and Cumaru Rosa), it is supposed that there should be only small differences in their tangential surfaces occurring after weathering. However, it has been shown that Cumaru Rosa reached a lower relative value of dilatation of the ray space at micro-cracks (Table 3 , Cumaru Rosa: $K_{\mathrm{N}} 54 \%$ and $K_{\mathrm{A}} 87 \%$; Cumaru: $K_{\mathrm{N}} 167 \%$ and $\left.K_{\mathrm{A}} 109 \%\right)$. Fragmentation of libriform fibres was similar in both Cumaru species, but more defibrillation was evident after natural outside weathering in Cumaru Rosa (Fig. $5^{\mathrm{B}} 3$ ). 
Table 3.

Visible cracks and micro cracks in the top surfaces of tropical woods created during weathering.

\begin{tabular}{|c|c|c|c|c|c|c|c|c|}
\hline \multirow[t]{3}{*}{ Trade name } & \multirow[t]{3}{*}{ Species } & \multicolumn{2}{|c|}{$\begin{array}{l}\text { Visible } \\
\text { crack* }^{*}\end{array}$} & \multicolumn{4}{|c|}{ Micro cracks in area of rays } & \multirow{3}{*}{$\begin{array}{c}\text { Ray } \\
\text { width } \\
(\mu \mathrm{m})\end{array}$} \\
\hline & & & & \multicolumn{2}{|c|}{ Natural weathering } & \multicolumn{2}{|c|}{ Artificial weathering } & \\
\hline & & $\mathrm{N}$ & A & $K_{\mathrm{N}}(\%)$ & $\mathrm{ABS}_{\mathrm{N}}$ width $(\mu \mathrm{m})$ & $K_{\mathrm{A}}(\%)$ & $\mathrm{ABS}_{\mathrm{A}}$ width $(\mu \mathrm{m})$ & \\
\hline \multirow[t]{2}{*}{ Bangkirai } & $\begin{array}{l}\text { Shorea obtusa } \\
\text { Wall. }\end{array}$ & 1.5 & 1 & 66 & $33 \pm 4.9$ & 49 & $29 \pm 12.7$ & $20 \pm 3.9$ \\
\hline & & & & ++ & & + & & \\
\hline \multirow[t]{2}{*}{ Cumaru } & $\begin{array}{l}\text { Dipteryx } \\
\text { odorata (Aubl.) } \\
\text { Wild. }\end{array}$ & 2.5 & 1 & 167 & $43 \pm 15 \cdot 0$ & 109 & $33 \pm 9 \cdot 1$ & $16 \pm 3 \cdot 7$ \\
\hline & & & & +++ & & +++ & & \\
\hline \multirow[t]{2}{*}{ Cumaru rosa } & $\begin{array}{l}\text { Dipteryx } \\
\text { magnifica } \\
\text { (Ducke) Ducke }\end{array}$ & 2.5 & 1 & 54 & $31 \pm 8.1$ & 87 & $38 \pm 8.3$ & $20 \pm 4.6$ \\
\hline & & & & ++ & & ++ & & \\
\hline \multirow[t]{2}{*}{ Ipé } & $\begin{array}{l}\text { Tabebuia } \\
\text { serratifolia } \\
\text { Nichols. }\end{array}$ & 1 & o & 148 & $44 \pm 8.7$ & 191 & $5^{2} \pm 12.8$ & $18 \pm 2.3$ \\
\hline & & & & +++ & & +++ & & \\
\hline \multirow[t]{2}{*}{ Jatobá } & $\begin{array}{l}\text { Hymenaea } \\
\text { courbaril L. }\end{array}$ & 1 & o & 23 & $48 \pm 24.4$ & 88 & $73 \pm 24 \cdot 5$ & $39 \pm 16.2$ \\
\hline & & & & + & & ++ & & \\
\hline \multirow[t]{2}{*}{ Kusia } & $\begin{array}{l}\text { Nauclea } \\
\text { diderrichii } \\
\text { Merill }\end{array}$ & 3 & 1.5 & 40 & $46 \pm 19.2$ & 42 & $47 \pm 20.9$ & $33 \pm 9 \cdot 0$ \\
\hline & & & & + & & + & & \\
\hline \multirow[t]{2}{*}{ Massaranduba } & $\begin{array}{l}\text { Manilkara } \\
\text { bidentata A. } \\
\text { Chev. }\end{array}$ & 2.5 & 1.5 & 139 & $5^{2} \pm 11.6$ & 95 & $42 \pm 8.4$ & $22 \pm 6.5$ \\
\hline & & & & +++ & & ++ & & \\
\hline
\end{tabular}

*Data from Reinprecht et al. (2018): o, no cracks; 1 , small cracks with a width of $0.1-0.3 \mathrm{~mm}$; 2, medium

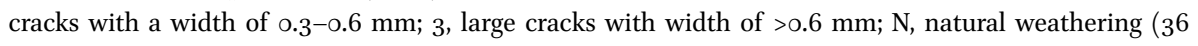
months); A, artificial weathering (12 weeks).

$\mathrm{K}$, relative dilatation of the ray space (at creation of micro crack); ABS, absolute dilatation of the ray space (micro crack); + , change of $<50 \%$; + , change of $50-100 \% ;+++$, change of $>100 \%$. Values are means \pm SD.

\section{CONCLUSIONS}

Based on previous experiments (Mamoňová 2017b), a new preparation methodology for SEM analyses of small specimens from natural and weathered extremely dense tropical hardwoods was suggested and verified, with the resulting scans to show the necessary information. 


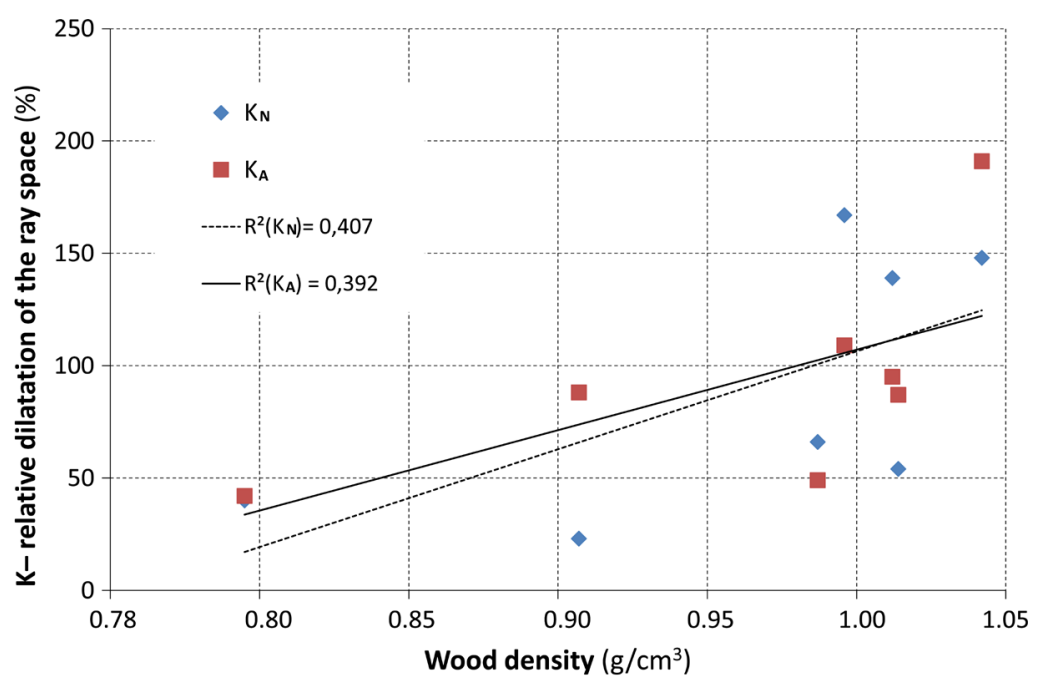

Note: $\mathbf{N}$-natural weathering (36 months), A-artificial weathering (12 weeks).

Figure 11. Dependence of dilatation of the ray spaces (micro-cracks) on the density of naturally and artificially weathered tropical hardwoods.

Anatomical analyses of seven tropical woods - Bangkirai, Cumaru, Cumaru Rosa, Ipé, Jatobá, Kusia and Massaranduba - performed before their weathering provided some new and expansive knowledge on their structure, as follows: incidence of fine helical thickenings on the vessel element walls of Kusia (Nauclea diderrichii); vestured pits of more precisely defined sizes and shape in vessels of Bangkirai (Shorea obtusa), Cumaru (Dipterix odorata), Cumaru Rosa (D. magnifica), and Jatobá (Hymenaea courbaril); specific microscopic features "sclerotic tyloses" in the vessel lumina determined for Massaranduba (Manilkara bidentata); the occurrence of organic compounds (naphthoquinone) in vessels and parenchyma cells of Ipé (Tabebuia serratifolia); microcrystals in the form of crystal sand located in ray cells of Kusia (Nauclea diderrichii).

Naturally and artificially weathered surfaces of all seven tropical hardwoods were characterised by typical structural changes in xylem tissues, as follows: defibrillation of cell elements as a result of weakening the connections between individual cell elements after degradation of the middle lamella and the $S_{1}$ layers containing mainly lignin; significant thinning of parenchyma cell walls and their extreme shrinkage, or their total degradation; micro-cracks, mainly in cell walls of rays and more evident in higher density tropical species, such as Cumaru (Dipterix odorata), Ipé (Tabebuia serratifolia), and Massaranduba (Manilkara bidentata); - fragile fractures of libriform fibres; - destruction and ablation of pit membranes in vessels and parenchyma cells; spherical formations on the $\mathrm{S}_{3}$ layer of cell walls produced from condensing compounds of degraded lignin and hemicelluloses at thermo-mechanical wrinkling.

Natural weathering also incurred some specific changes in the anatomy of tropical woods, for example, connected with adsorption of dust particles, spores, or occasionally 
pollen grains into the empty spaces created in areas of the severely degraded parenchyma rays as well as in cracks and micro-cracks.

\section{ACKNOWLEDGEMENTS}

This work was supported by the Slovak Research and Development Agency under the contracts No. APVV17-0583 and No. APVV-16-0177.

\section{REFERENCES}

Alves ES, Angyalossy-Alfonso V. 2002. Ecological trends in the wood anatomy of some Brazilian species. 2. Axial parenchyma, rays and fibres. IAWA J. 23: 391-418. DOI: 10.1163/22941932-90ooo311.

Anderegg WRL, Meinzer FC. 2015. Wood anatomy and plant hydraulics in a changing climate. In: Hacke U (ed.), Functional and ecological xylem anatomy. Springer International Publishing, Cham: $235^{-253}$.

Barreto CCK, Pastore TCM. 20og. Resistance to artificial weathering of four tropical woods: the effect of the extractives. Ciência Florestal 19: 23-30.

De Micco V, Balzano A, Wheeler EA, Baas P. 2016. Tyloses and gums: a review of structure, function and occurrence of vessel occlusions. IAWA J. 37: 186-205. DOI: 10.1163/22941932-20160130.

Derbyshire H, Miller ER, Turkulin H. 1996. Investigations into the photodegradation of wood using microtensile testing. Part 2: an investigation of the changes in tensile strength of different softwood species during natural weathering. Holz Roh-Werkstoff 54: 1-6.

Dos Santos G, Miller RB. 1992. Wood anatomy of Tecomeae. In: Flora neotropica monograph 25 (II). Bignoniaceae, part II (Tribe Tecomeae). The New York Botanical Garden Press, New York, NY: $336-358$.

Evans PD, Haase JG, Seman ASBM, Kiguchi M. 2015. The search for durable exterior clear coatings for wood. Coatings 5: 830-864. DOI: 10.339o/coatings504083o.

Feist WC, Hon DNS. 1984. Chemistry of weathering and protection. In: The chemistry of solid wood. Adv. chem. ser. 207: 401-451. DOI: 10.1021/ba-1984-0207.cho11.

Fern K, Fern A, Morris R. 2014. The useful tropical plants database. Last update 20 November 2018.

Gasson P. 1999. Wood anatomy of the tribe Dipterygeae with comments on related papilionoid and caesalpinioid leguminosae. IAWA J. 20: 441-455. DOI: 10.1163/22941932-90001570.

Grace JK, Tome CHM. 2005. Resistance of the Indonesian woods bangkirai (Shorea laevis) and merbau (Lutsia palembanica) to Formosan subterranean termite attack. Sociobiology 45: 5०3-509.

Hernández RE. 2007. Swelling properties of hardwoods as affected by their extraneous substances, wood density, and interlocked grain. Wood Fib. Sci. 39: 146-158.

Hernández RE, Almeida G. 2003. Effects of wood density and interlocked grain on the shear strength of three Amazonian tropical hardwoods. Wood Fib. Sci. 35: 154-166.

Hussain H, Krohn K, Ahmad VU, Miana GA, Green IR. 2007. Lapachol: an overview. Arkivoc 2:145-171. DOI: 10.3998/ark.5550190.00o8.204.

Ilic J. 1991. CSIRO atlas of hardwoods. Springer-Verlag, Berlin.

ITTO. 2017. Tropical timber market report: 21:21, 2017. International Tropical Timber Organization (ITTO), Yokohama.

Jankowska A, Drożdżek M, Sarnowski P, Horodeński J. 2016. Effect of extractives on the equilibrium moisture content and shrinkage of selected tropical wood species. BioResources 12: 597-6o7.

Jansen S, Baas P, Gasson P, Lens F, Smets E. 2004. Variation in xylem structure from tropics to tundra: evidence from vestured pits. Proc. Natl. Acad. Sci. 101: 8833-8837. DOI: 10.1073/pnas.0402621101.

Kučera LJ, Sell J. 1987. Weathering behaviour of beech wood in the ray tissue region. Holz RohWerkstoff 45: 89-93. 
Lacasta AM, Haurie L, Monton J, Navarro Ezquerra A, Giraldo P, Sotomayor J, Palumbo M. 2016. Characterization of the fire behaviour of tropical wood species for use in the construction industry. In: WCTE 2016 - World Conference on Timber Engineering. Viena, Technischen Universität Graz, 2016: 5387-5395. ISBN: 978-3-903024-35-9.

Lewis GP, Gasson P. 2000. A new combination in the genus Dipteryx (Leguminosae: Papilionoideae). Kew Bull. 55: 247-248. DOI: 10.2307/4117788.

Mamoňová M. 2017a. Anatomic and spectrophotometric differentiation of Dalbergia nigra from other species of rosewood. Acta Facultatis Xylologiae Zvolen 59: $5^{-16}$.

Mamoňová M. 2017b. 3D wood analysis using electron microscope. In: 2nd International conference ${ }_{3} \mathrm{D}$ measurement and imaging. Science and Education Agency, Bratislava: $236-318$. ISBN: 978-8o967907-1-5.

Melandri JL, Espinoza de Pernía N. 2oog. Wood anatomy of tribe Detarieae and comparison with tribe Caesalpinieae (Leguminosae, Caesalpinioideae) in Venezuela. Revista de Biología Tropical 57: 303-319.

Nardi BR, Edlmann Abbate ML. 1992. Legnami tropicali importati in Italia: anatomia e identificazione. Vol. II. America Latina. CNR, Firenze. 406 p.

Ogata K, Fujii T, Abe H, Baas P. 2008. Identification of the timbers of southeast Asia and the western Pacific. Kaiseisha Press, Otsu. ISBN: 978-4-86o99-93o-8 (eBook).

Oliver R. 2015. Europe's changing tropical timber trade: baseline report of the independent market monitoring initiative. ITTO technical series no. 45. International Tropical Timber Organization, Yokohama. ISBN: 978-4-86507-027-9.

Onuorah EO. 200o. The wood preservative potentials of heartwood extracts of Milicia excelsa and Erythrophleum suaveolens. Bioresource Technol. 75:171-173. DOI:10.1016/So96o-8524(99)oo165-o.

Owen JA, Owen NL, Feist WC. 1993. Scanning electron microscope and infrared studies of weathering in southern pine. J. Mol. Struct. 300: 105-114.

Pace MR, Lohmann LG, Olmstead RG, Angyalossy V. 2015. Wood anatomy of major Bignoniaceae clades. Plant Systematics and Evolution 301: 967-995. DOI: 10.1007/soo6o6-014-1129-2.

Pánek M, Reinprecht L. 2016. Effect of vegetable oils on the colour stability of four tropical woods during natural and artificial weathering. J. Wood Sci. 62: 74-84.

Rana R, Langenfeld-Heyser R, Finkeldey R, Polle A. 20o9. Functional anatomy of five endangered tropical timber wood species of the family Dipterocarpaceae. Trees 23: $5^{21-529}$. DOI: $10.1007 /$ soo468-0o8-0298-4.

Reinprecht L, Kmet'ová L, Iždinský J. 2012. Fungal decay and bending properties of beech plywood overlaid with tropical veneers. J. Trop. For. Sci. 24: 49o-497.

Reinprecht L, Mamoňová M, Pánek M, Kačík F. 2018. The impact of natural and artificial weathering on the visual, colour and structural changes of seven tropical woods. Eur. J. Wood Prod. 76: 17519o. DOI: 10.1007/so0107-017-1228-1.

Richter HG, Dallwitz MJ. 20oo. Commercial timbers: descriptions, illustrations, identification, and information retrieval. In English, French, German, Portuguese, and Spanish. Version 25June 2009. Available online at http://delta-intkey.com.

Sandak A, Sandak J, Burud I, Gobakken LR. 2016. Weathering kinetics of thin wood veneers assessed with near-infrared spectroscopy. J. Near Infrared Spectrosc. 24: 549-553. DOI: 10.1255/jnirs.1230.

Sandberg D, Söderström O. 2006. Crack formation due to weathering of radial and tangential sections of pine and spruce. Wood Mat. Sci. Eng. 1: 12-20. DOI: 10.1080/174802706oo644407.

Schulte A, Schöne D. 1996. Dipterocarp forest ecosystems: towards sustainable management. World Scientific Publishing, Singapore. ISBN: 9789810227296.

Turkulin H, Sell J. 1997. Structural and fractographic study on weathered wood. An application of FE SEM microscopy to the "Thin strip" method. Research- and Work Report 115/36. EMPA. Dübendorf. 
Turkulin H, Sell J. 2002. Investigations into the photodegradation of wood using micro tensile testing. Part 4: tensile properties and fractography of weathered wood. Holz Roh-Werkstoff 6o: 96-105. DOI: $10.1007 /$ soo107-002-0282-4.

UNECE. 2017. Forest products annual market review 2016-2017. Geneva Timber and Forest Study Papers No. 41. United Nations Economic Commission for Europe, Geneva, Switzerland.

Wagenführ R. 2007. Holzatlas. 6., neu bearb. und erweit. Aufl. Fachbuchverlag, Leipzig. ISBN: 978-3446-40649-o.

Waliszewska B, Zborowska M, Prądzyński W, Robaszyńska M. 20o6. Chemical composition of selected species of exotic trees. In: Wood structure and properties'o6: 171-174. Arbora Publishers, Zvolen. ISBN: 8o-968869-4-3.

Wheeler EA, Baas P, Gasson PE (eds.). 1989. IAWA list of microscopy features for hardwood identification. IAWA Bull. n.s. 10: 219-332.

Wheeler EA. 2011. InsideWood — a web resource for hardwood anatomy. IAWA J. 32: 199-211. DOI: 10. 1163/22941932-90000051.

Williams RS. 2005. Weathering of wood. In: Rowell RM(ed.), Handbook of wood chemistry and wood composites. CRC Press, Boca Raton, FL: 139-185.

Edited by Lloyd Donaldson 